\title{
Analisis Coverage Planning dan Coverage Prediction di Existing Network eNodeB Jaringan 4G di Daerah Operasional Yogyakarta dan Magelang
}

\author{
Pilar Tiara Lelepadang1, Eva Yovita Dwi Utami'2 ${ }^{2}$ Andreas Ardian Febrianto ${ }^{3}$ \\ Program Studi Teknik Elektro, \\ Fakultas Teknik Elektronika dan Komputer, \\ Universitas Kristen Satya Wacana, Salatiga \\ 1Rrrara922@gmail.com, ²eva.utami@staff.uksw.edu, 3andreas.febrianto@staff.uksw.edu
}

\begin{abstract}
Ringkasan
Untuk meningkatkan kinerja jaringan 4G yang merupakan jaringan uji coba di Yogyakarta dan Magelang maka harus dilakukan coverage planning pada daerah yang kurang optimal. Kurang optimalnya daerah ini dikarenakan cakupan dan kualitas Radio Frequency (RF) masih belum memenuhi standar yang sudah ditetapkan oleh perusahaan. Hal ini terlihat pada hasil drive test daerah operasional. Solusi yang permanen, yakni pembangunan site baru dapat mengoptimalkan RF yang belum memenuhi standar perusahaan. Selain itu, untuk menjaga kualitas site baru agar tidak terjadi interferensi maka perlu dilakukan perencanaan Physical Cell Identity (PCI). PCI merupakan identitas site yang berbentuk kode angka 0 sampai 503. Parameter RF yang diteliti ialah Reference Signal Received Power (RSRP) dan Signal to Interference Noise Ratio (SINR). Analisis hasil drive test menurut parameter RF akan menghasilkan rekomendasi pembangunan site baru. Rekomendasi tersebut disimulasikan cakupan areanya dalam bentuk coverage prediction yang merupakan simulasi dengan planning tools U-Net. Dari hasil simulasi ini, didapatkan 50\% cakupan area pada Yogyakarta memiliki RSRP yang semula $-99,17 \mathrm{dBm}$ menjadi $-98,78 \mathrm{dBm}$ dan untuk Magelang yang semula $-96,51 \mathrm{dBm}$ menjadi $-95 \mathrm{dBm}$. Sementara, SINR pada Yogyakarta meningkat rata-ratanya dari $1,03 \mathrm{~dB}$ menjadi $1,18 \mathrm{~dB}$ dan pada Magelang meningkat rataratanya dari $2,23 \mathrm{~dB}$ menjadi $2,55 \mathrm{~dB}$.
\end{abstract}

Kata kunci: Coverage Planning, RSRP ,SINR, PCI

\section{Pendahuluan}

Kinerja jaringan 4G yang dibangun oleh PT.Indosat Ooredoo pada kurun waktu Maret 2016 hingga Agustus 2016 merupakan jaringan uji coba yang diklaim telah mencakup 95\% daerah operasionalnya. Meskipun demikian, masih terdapat area yang memiliki distribusi RSRP dan SINR yang kurang optimal atau biasa disebut bad spot area. Bad spot area ini dapat dievaluasi dengan menggunakan hasil drive test yang menunjukkan distribusi parameter RF. Terdapat dua solusi untuk mengatasi masalah bad spot area, yakni konfigurasi antena, dan penambahan site. Contoh penerapan solusi dengan konfigutasi antena diteliti pada [1], dengan penelitian dilakukan di kota Purbalingga. Terdapat permasalahan yang timbul ketika dilakukan optimasi hanya dengan melakukan konfigurasi antena. Permasalahan tersebut ialah ketika cakupan 
dikurangi maka daya, dalam hal ini disebut RSRP, juga akan menurun distribusinya. Kinerja RSRP yang turun akan mempengaruhi kualitas atau parameter SINR pada daerah operasional. Dalam penelitian ini dibahas solusi penambahan site untuk meningkatkan cakupan dan mengurangi site dominan yang menyebabkan interferensi. Sehingga dengan meningkatnya nilai RSRP maka SINR juga akan meningkat. Peningkatan SINR dapat membuat kanal downlink menjadi lebih baik. Selain itu, hal ini dianggap sebagai rekomendasi yang baik, mengingat jaringan 4G PT.Indosat Ooredoo pada rentang waktu Maret 2016 hingga Agustus 2016 masih tergolong jaringan uji coba.

Dalam penelitian ini, juga dilakukan pemberian skenario PCI pada penambahan site. Hal ini pernah dilakukan dengan kondisi pemberian PCI masih dalam kondisi initial coverage planning[2]. Berbeda dengan penelitian tersebut, pada penelitian ini dilakukan pemberian skenario PCI pada penambahan site di existing network. Pemberian PCI dilakukan agar tidak terjadi interferensi antar Reference Signal karena Reference Signal akan tergantung pada pemberian kode PCI.

\section{Metode Penelitian}

\subsection{Metode Pengambilan Data}

\subsubsection{Drive Test}

Drive Test ialah pengujian unjuk kerja jaringan telekomunikasi melalui hasil pengukuran Key Paramater Indicator. Metode drive test yang dilakukan mempunyai rute drive test. Hasil drive test yang merujuk rute drive test disebut baseline area, karena rute dirancang untuk mencerminkan distribusi trafik yang diharapkan dan distribusi area layanan. Kegunaan baseline area ialah untuk mengidentifikasi badspot area.

Pengumpulan data melalui drive test dilakukan dua kali, yaitu sesudah dilakukan drive test pertama pada bulan Maret 2016, dan setelah dilakukan drive test kedua pada bulan Agustus 2016.

\subsubsection{Engineer Parameter}

Data kedua, berupa engineer parameter yang digunakan untuk membuat area yang berisi parameter perencanaan cakupan. Pengambilan data ini berdasarkan pada drive test pertama dan kedua. Selain itu, data yang digunakan berisi database site yang diberi kelompok sebagai berikut [3].

a. Kelompok site terdiri nama dan tipe site

b. Kelompok transceiver, meliputi:

1. Azimuth untuk penentuan sektor dan rute drive test,

2. Model antena yang digunakan,

3. Tinggi antena yang digunakan,

4. Tilting antena dan total kerugian transmisi.

c. Kelompok General, meliputi:

1. Max Power, yang menyatakan kuat transmisi

2. Frequency Band, yang menyatakan frekuensi yang digunakan

3. Model Transmisi, yang menyatakan konfigurasi $e N b$ yang digunakan pada pengambilan data model transmisi yang digunakan, yaitu TM2 yang menunjukkan open loop transmit diversity.

4. RS Power, yang menyatakan kuat isyarat referensi yang digunakan. 
d. Kelompok Model Propagasi, meliputi parameter sebagai berikut.

1. Model Propagasi, untuk menentukan model propagasi yang digunakan.

2. Radius, untuk mengidentifikasi radius model propagasi yang digunakan.

3. Resolution, untuk menghitung resolusi model propagasi yang digunakan.

\subsubsection{Parameter yang Digunakan}

Beberapa tipe parameter pengukuran dibuat di User Equipment dan eNodeB. Beberapa parameter ini akan menjadi tolok ukur dalam penelitian ini dan merupakan parameter untuk perencanaan cakupan [4]. Parameter yang dimaksud ialah sebagai berikut .

a. Reference Signal Received Power (RSRP)

$R S R P$ adalah suatu parameter yang digunakan untuk sel tertentu yang dianggap sebagai rata-rata kuat isyarat resource element yang membawa isyarat referensi sel spesifik dalam pengukuran pita frekuensi [5]. RSRP sangat dipengaruhi oleh daya pancar sel, path loss dan fading. Untuk standar yang digunakan perusahaan dapat dilihat pada Tabel 1.

Tabel 1. Standarisasi Parameter RSRP PT.Indosat Ooredoo
\begin{tabular}{|l|c|c|}
\hline Kekuatan Sinyal & Kode Warna & Nilai RSRP $(\mathrm{dBm})$ \\
\hline Sangat baik & - & $R S R P>-80$ \\
\hline Baik & - & $-90=<R S R P<-80$ \\
\hline Cukup baik & - & $-100=<R S R P<-90$ \\
\hline Cukup & & $-105=\leq R S R P R<-100$ \\
\hline Cukup buruk & & $-110=\leq R S R P<-105$ \\
\hline Buruk & & $-116=\leq R S R P<-110$ \\
\hline Sangat Buruk & & $-120=<R S R P<-116$ \\
\hline No Sinyal & - & $R S R P<-120$ \\
\hline
\end{tabular}

b. Signal to Interference Noise Ratio (SINR)

SINR adalah rasio yang antara daya rata-rata isyarat yang diterima dengan interferensi dan derau [4]. Nilai SINR dihitung dari RSRP sel serving dan dari interferensi sel [2]. Untuk standar yang digunakan perusahaan dapat dilihat pada Tabel 2.

\begin{tabular}{l|c|c|}
\multicolumn{3}{c}{ Tabel 2. Standarisasi Parameter SINR PT. Indosat Ooredoo } \\
\hline \multicolumn{1}{c|}{ Kualitas sinyal } & Kode Warna & Nilai SINR \\
\hline Sangat baik & - & SINR $>20$ \\
\hline Baik & & $13=<S I N R<20$ \\
\hline Cukup & & $0=<S I N R<13$ \\
\hline Buruk & 0 & $S I N R<0$ \\
\hline
\end{tabular}

c. Channel Quality Indicator (CQI)

CQI digunakan untuk merepresentasikan kanal downlink yang aktif. CQI juga menunjukkan nomer indeks yang akan menjadi acuan untuk melihat orde modulasi yang terjadi pada kanal. Untuk standar indeks CQI dan modulasinya dapat dilihat Tabel 3

\begin{tabular}{|l|l|l|}
\hline \multicolumn{3}{|c|}{ Tabel 3. Indeks CQI. } \\
\hline Indeks $C Q I$ & Modulasi & Bit/Simbol \\
\hline $\mathbf{1 - 6}$ & QPSK & 2 \\
\hline $7-9$ & $16 \mathrm{QAM}$ & 4 \\
\hline $\mathbf{1 0 - 1 5}$ & $64 \mathrm{AM}$ & 6 \\
\hline
\end{tabular}




\subsection{Metode Pengolahan Data}

Pengolahan data yang dilakukan dalam penelitian ditunjukkan oleh Gambar 1. Sementara untuk penjabaran masing-masing tahap dijabarkan sebagai berikut.

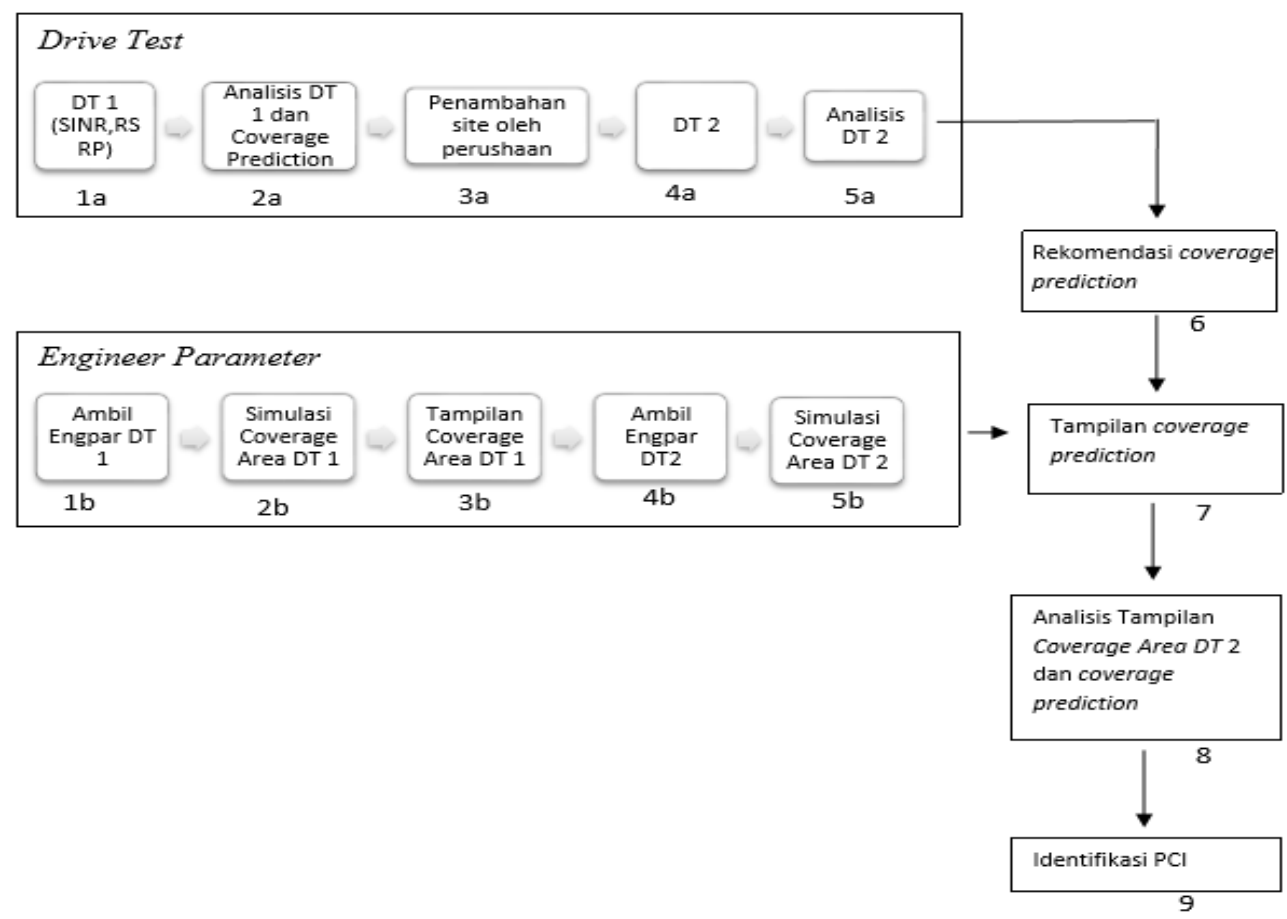

Gambar 1. Langkah-langkah Pengolahan Data

1. Analisis Coverage Planning di Existing Network Berdasarkan Pemetaan Hasil Drive Test

Tahap ini merupakan tahap pertama yang ditunjukkan pada Nomer 1a hingga 5a pada Gambar 1. Setelah dilakukan drive test pertama maka dilakukan analisis bad spot dan coverage planning di existing network oleh perusahaan. Setelah itu terjadi penambahan site yang dianggap memiliki revenue bagi perusahaan. Drive test kedua kemudian dilakukan sesudah optimasi dilaksanakan oleh perusahaan sehingga dapat dilakukan analisis bad spot.

2. Membuat Tampilan Coverage Area pada Daerah yang Diteliti

Tahap ini ditunjukkan pada Nomer $1 \mathrm{~b}$ hingga $5 \mathrm{~b}$ pada Gambar 1.Tampilan coverage area ini merupakan hasil simulasi engineer parameter yang diolah di planning tools U-Net. Waktu pengambilan engineer parameter diambil berdasarkan waktu terjadinya drive test. Hasil statistik dalam bentuk Cumulative Density Function ditampilkan juga pada tahap ini.

3. Membuat Coverage Prediction pada Daerah yang Diteliti

Setelah dilakukan identifikasi badspot area dan simulasi coverage area maka dapat dilakukan rekomendasi penambahan site.Tahap ini ditunjukkan pada langkah 6 pada Gambar 1. Rekomendasi tersebut akan menjadi landasan untuk membuat coverage area yang kemudian dijadikan coverage prediction. Hasil coverage prediction akan dibandingkan dengan hasil coverage area yang memiliki kondisi site sama dengan kondisi drive test, sehingga dapat dilihat perbaikan kinerja parameter yang terjadi setelah dilakukan rekomendasi penambahan site. Langkah dalam 
melakukan coverage prediction yang berkaitan dengan rekomendasi penambahan site berdasarkan drive Test dan tampilan coverage area ditunjukkan pada nomor 7 Gambar 1.

4. Melakukan identifikasi PCI pada Daerah yang Diteliti

Identifikasi alokasi data $P C I$ akan dilakukan untuk menganalisis pemilihan skenario perencanaan. Penghitungan alokasi PCI untuk penambahan site disajikan dalam bentuk tabel dengan memperhitungkan PCI modulonya. Tabel tersebut digunakan untuk memberikan kemungkinan posisi cell reference signal sehingga tidak terjadi kolusi dengan neighbor cell.

\section{Hasil Penelitian dan Analisis}

\subsection{Analisis Berdasarkan Pemetaan Parameter RSRP Hasil Drive Test}

\subsubsection{Daerah Operasional Yogyakarta}

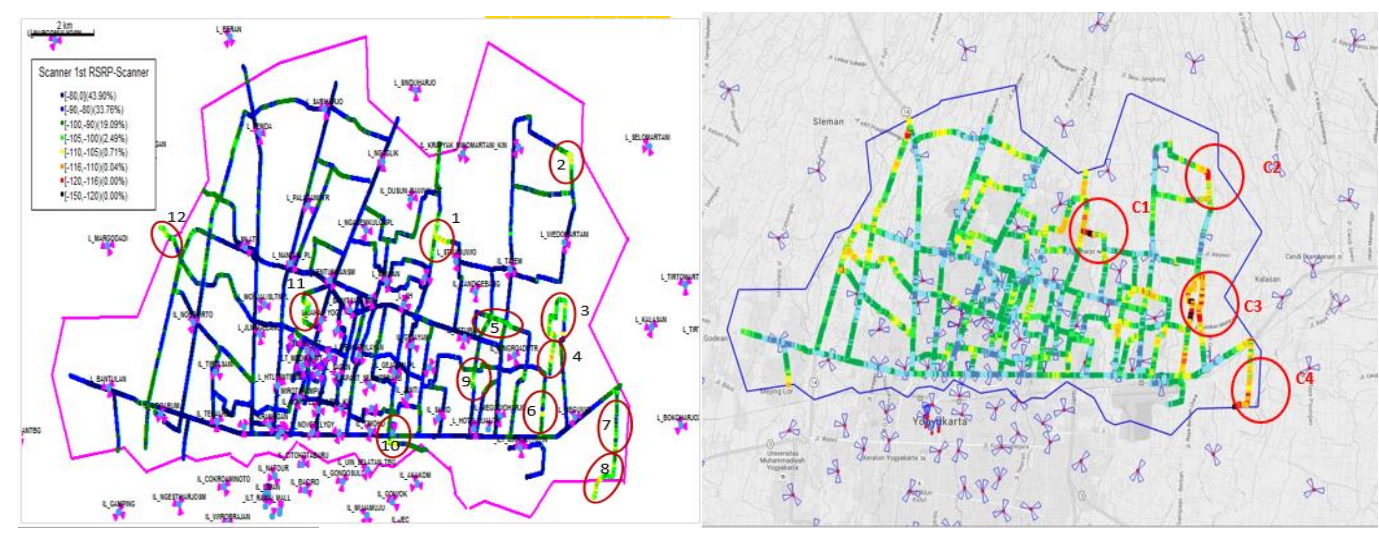

(a)

(b)

Gambar 2. Hasil Drive Test RSRP Daerah Operasional Yogyakarta (a) Drive Test Pertama (b) Drive Test Kedua

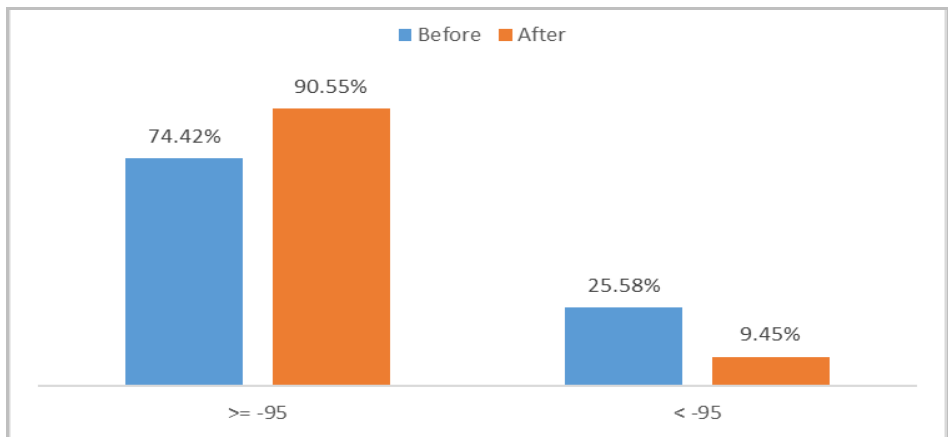

Gambar 3. Perbandingan persentase RSRP Sebelum dan Sesudah Drive Test Daerah Yogyakarta

Gambar 2 menunjukkan distribusi RSRP untuk daerah operasional Yogyakarta yang memiliki morfologi urban. Pada daerah ini awalnya memiliki empat titik badspot dengan kuat isyarat atau distribusi $R S R P$ sebesar $-110 \mathrm{dBm}$ hingga $-125 \mathrm{dBm}$ seperti pada Gambar 2(a). Titik badspot tersebut kemudian dioptimalisasi cakupannya dan dilakukan penambahan 4 site oleh perusahaan. Dari Gambar 2(a) dan Gambar 2(b) dapat dilihat jumlah badspot mungkin bertambah tetapi dengan nilai RSRP yang lebih baik. Pembangunan site L_STMAGUWO pada badspot C1 dapat meningkatkan kinerja RSRP 
secara keseluruhan karena mampu menutupi coverage hole. Perbaikan RSRP dapat dilihat pada Gambar 3, yaitu terjadi peningkatan persentase RSRP > -95 dBm sebesar 16,13\% setelah dilakukan optimalisasi.

\subsubsection{Daerah Operasional Magelang}

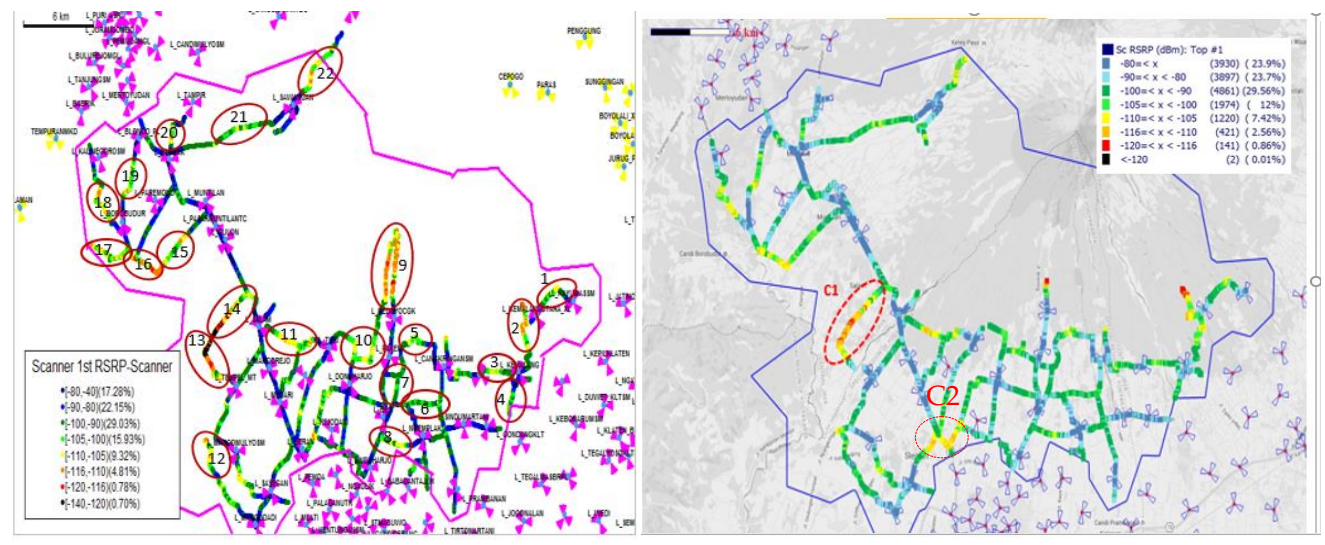

Gambar 4. Hasil Drive Test RSRP Daerah Operasional Magelang (a) Drive Test Pertama (b) Drive Test Kedua

Pada daerah Magelang, distribusi RSRP hasil drive test pertama seperti pada Gambar 4(a) tergolong cukup baik hanya terdapat dua badspot. Drive test kedua dilakukan setelah dilakukan penambahan satu site yaitu L_BERAN pada badspot C2. Namun hasil drive test menunjukkan bahwa persentase RSRP yang baik (pada Gambar 5) menurun sebesar $8,67 \%$ yang disebabkan oleh munculnya bad spot baru. Bad spot yan muncul setelah drive test kedua ialah badspot Nomor 14 dengan kasus coverage hole akibat cross coverage pada L_BOROBUDUR dan L_TEMPEL sehingga nilai distribusi parameter secara keseluruhan menurun.

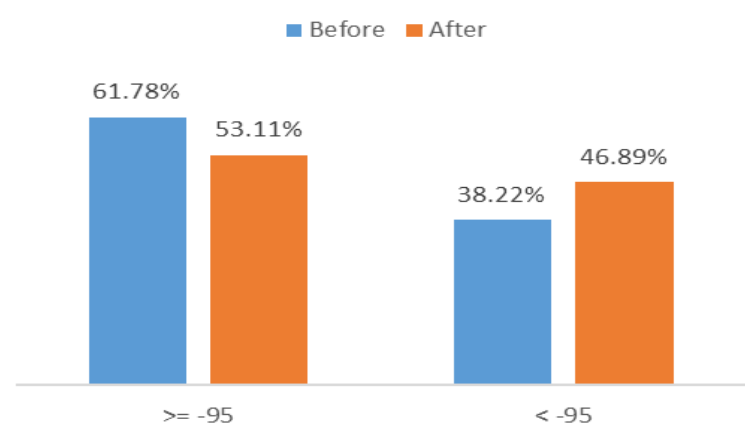

Gambar 5. Perbandingan persentase RSRP Sebelum dan Sesudah Drive Test Daerah Magelang

\section{2. $\quad$ Analisis Hasil Drive Test Parameter SINR}

\subsubsection{Daerah Operasional Yogyakarta}

Gambar 6 menunjukkan distribusi SINR untuk daerah operasional Yogyakarta. Pengaruh penambahan empat site baru ditunjukkan pada hasil drive test kedua. Grafik pada Gambar 7 menunjukkan terjadi penurunan persentase nilai SINR $>10$ sebesar $26,28 \%$. Lack of dominant cell yang menyebabkan interferensi tinggi sejak dari drive test pertama ke drive test kedua menjadi salah satu penyebab munculnya badspot. Dibutuhkan penambahan site setelah drive test kedua untuk mengurangi site dominan yang menyebabkan interferensi. Terlihat pada Gambar 6 (a) dan Gambar 6(b) bahwa distribusi 
SINR kebanyakan berwarna kuning. Hal ini menunjukkan besar SINR berkisar $7 \mathrm{~dB}$ hingga -7 dB sehingga jika dicocokkan nilai tersebut setara dengan indeks CQI 1 hingga 6 dan modulasi yang terjadi ialah QPSK. Meskipun demikian daya yang meningkat, seperti disampaikan pada Bagian 3.1.1, masih bisa mempertahankan jaringan agar tetap terkoneksi.

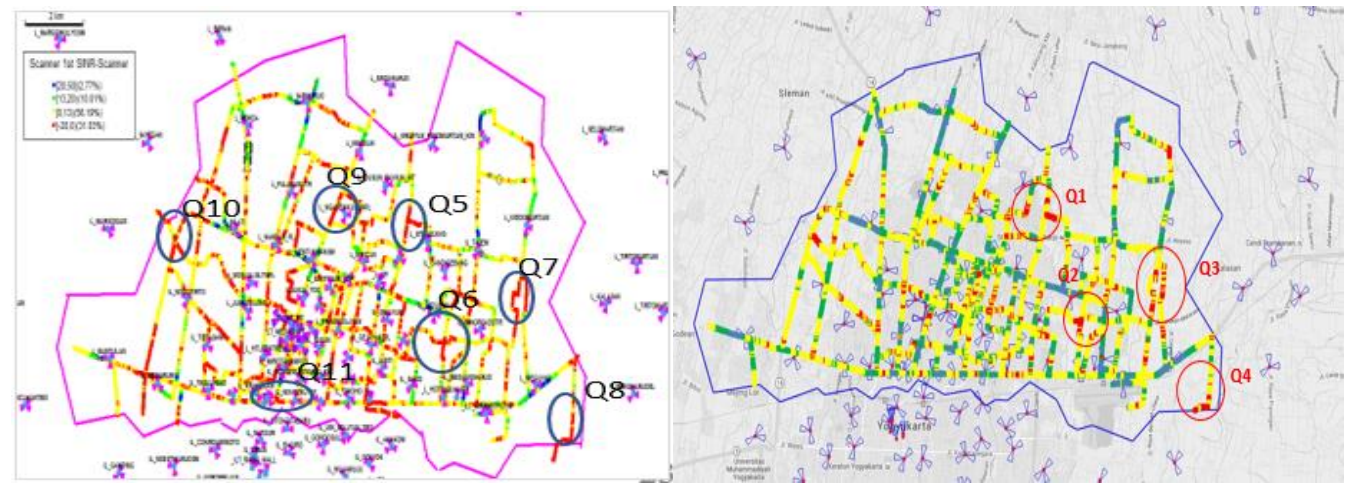

(a)

(b)

Gambar 6. Hasil Drive Test SINR Daerah Operasional Yogyakarta (a) Drive Test Pertama (b) Drive Test Kedua

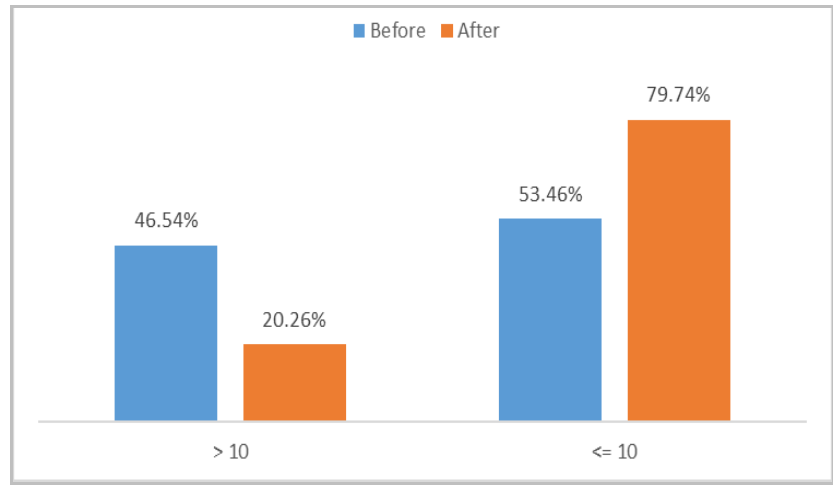

Gambar 7. Persentase SINR Sebelum dan Sesudah Drive Test Daerah Yogyakarta

\subsubsection{Daerah Operasional Magelang}

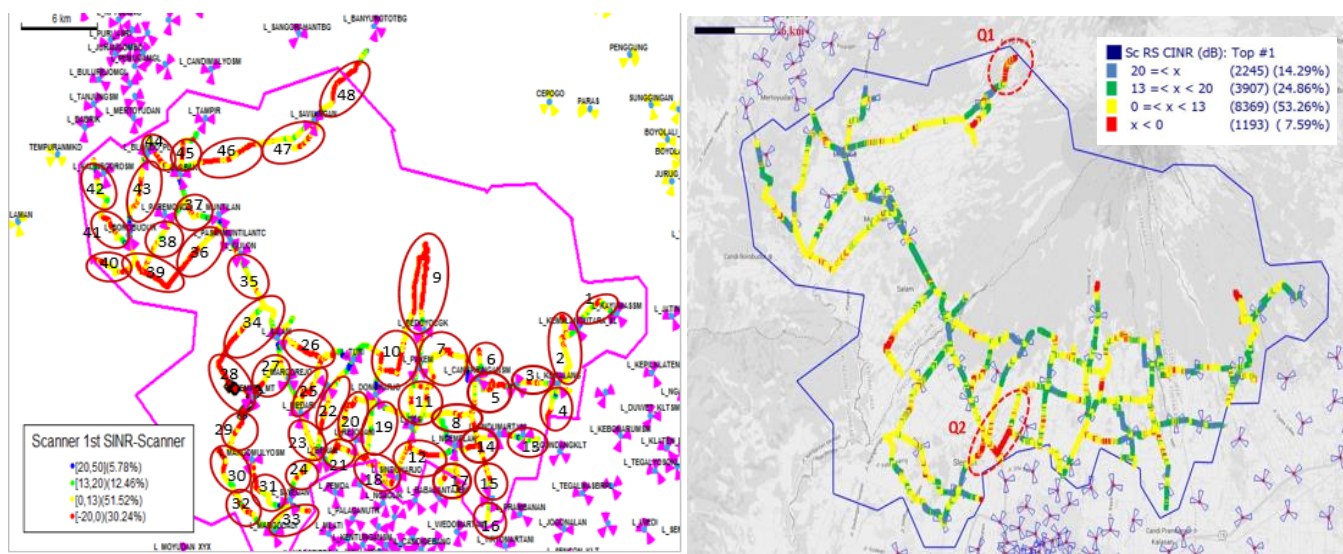

(a)

(b)

Gambar 8. Hasil Drive Test SINR Daerah Operasional Magelang (a) Drive Test Pertama (b) Drive Test Kedua 
Distribusi parameter SINR pada daerah Magelang ditunjukkan pada Gambar 8(a) dan Gambar 8(b). Terjadi penurunan SINR sekitar 2,82\% seperti pada Gambar 9. Berbeda dengan kondisi RSRP di Bagian 3.1.2, badspot C2 menunjukkan kinerja SINR yang lebih buruk dibandingkan dengan badspot $\mathrm{C} 1$, meskipun kuat isyaratnya sama. Sehingga L_BERAN dibangun untuk menutupi badspot C2. Buruknya RSRP menyebabkan penurunan SINR pada drive test kedua. Sehingga direkomendasikan pembangunan site yang sama dengan rekomendasi $R S R P$ untuk menutupi buruknya SINR yang disebabkan oleh rendahnya $R S R P$.

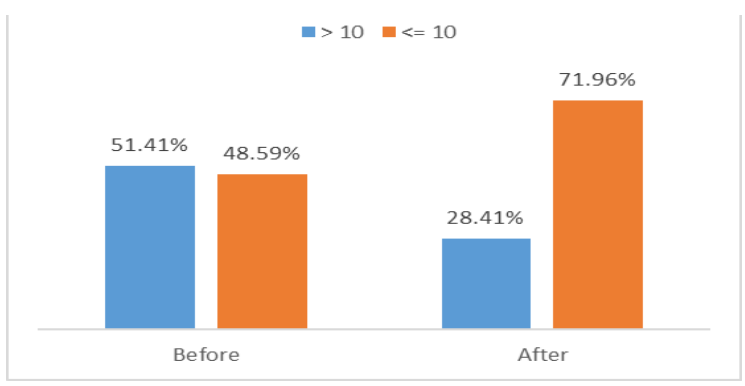

Gambar 9. Persentase SINR Sebelum dan Sesudah Drive Test Daerah Magelang

\subsection{Coverage Area dan Coverage Prediction}

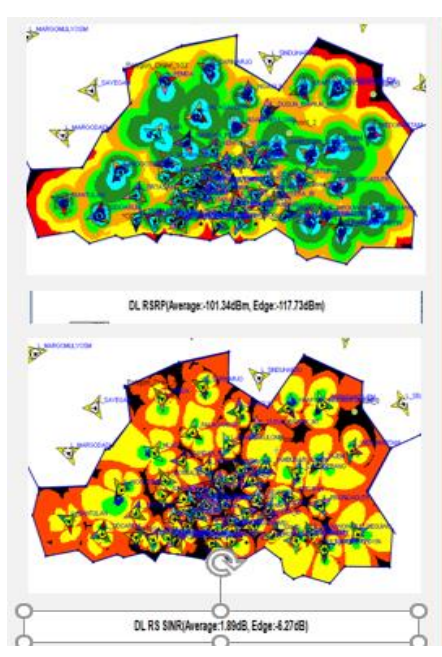

(a)

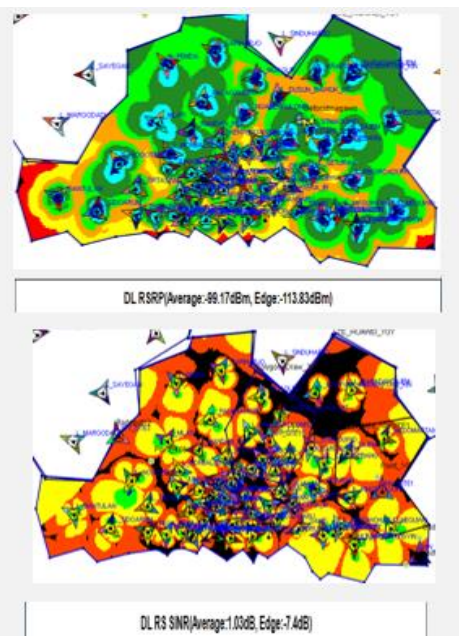

(b)

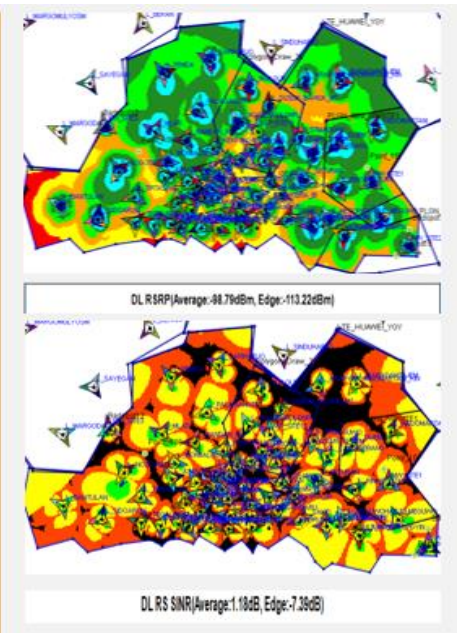

(c)

Gambar 10. Coverage Area Daerah Operasional Yogyakarta (a) Drive Test Pertama (b) Drive Test Kedua (c) Coverage Prediction

Coverage area drive test pertama dan kedua ditampilkan pada Gambar 10(a) dan Gambar 10(b), sedangkan Gambar 10(c) merupakan hasil coverage prediction. Keterangan untuk setiap warna level RSRP pada gambar dapat dilihat pada Tabel 1, untuk setiap warna level SINR dapat dilihat pada Tabel 2. Coverage Area merupakan hasil simulasi dengan menggunakan engineer parameter. Diperoleh bahwa 50\% sampel pengukuran daerah operasional mengalami peningkatan kuat isyarat, dari semula $-101,34 \mathrm{dBm}$ menjadi -99,17 dBm; sementara untuk SINR terjadi penurunan, yakni dari semula memiliki rata-rata $1,89 \mathrm{~dB}$ menjadi $1,03 \mathrm{~dB}$. Hal ini sama seperti yang terjadi pada drive test. Untuk selanjutnya, ditunjukkan coverage prediction pada Gambar 10(c). Dapat dilihat bahwa coverage prediction mampu memperbaiki RSRP cakupan menjadi -98,78 dBm dan SINR meningkat menjadi 1,18 dB. Untuk peningkatan kinerja yang lebih optimal dapat 
dilihat pada Tabel 4. Untuk daerah Yogyakarta yang memiliki luas sekitar 122,56 km², dilakukan penambahan 4 site direkomendasikan untuk mengurangi badspot yang kemudian dibagi juga menjadi 4 polygon, masing-masing polygon berisi 1 site. Dari Tabel 4 diketahui semua polygon mengalami peningkatan SINR dan RSRP.

Tabel 4. Hasil Coverage Prediction Parameter RSRP dan SINR Daerah Operasional Yogyakarta

\begin{tabular}{|c|c|c|c|c|c|c|c|c|}
\hline \multirow{2}{*}{ Nama Site } & \multicolumn{3}{|c|}{$50 \%$ RSRP $(\mathrm{dBm})$} & \multicolumn{3}{c|}{$50 \%$ SINR(dB } \\
\cline { 2 - 9 } & \multicolumn{2}{|c|}{ Before } & \multicolumn{2}{c|}{ After } & \multicolumn{3}{c|}{ Before } & \multicolumn{3}{c|}{ After } \\
\hline NW_SITE1 & $-97,18$ & -107.22 & $-96,53$ & $-107,22$ & 1,99 & $-5,36$ & 2,09 & $-5,68$ \\
\hline NW_SITE2 & $-104,54$ & -121 & $-99,25$ & $-111,46$ & 1,69 & $-1,74$ & 4.07 & $-3,72$ \\
\hline NW_SITE3 & $-97,54$ & $-108,9$ & $-96,6$ & $-108,9$ & 1,81 & $-4,95$ & 1,86 & $-5,9$ \\
\hline NW_SITE15 & $-97,91$ & $-108,89$ & $-96,71$ & $-108,43$ & 0.08 & -8.12 & 0.33 & -8.12 \\
\hline
\end{tabular}

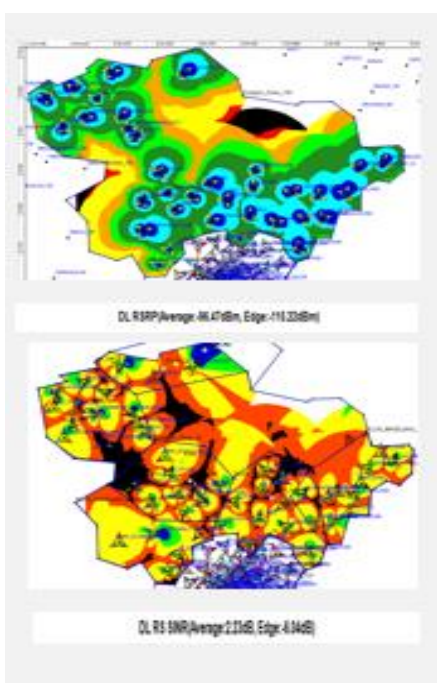

(a)

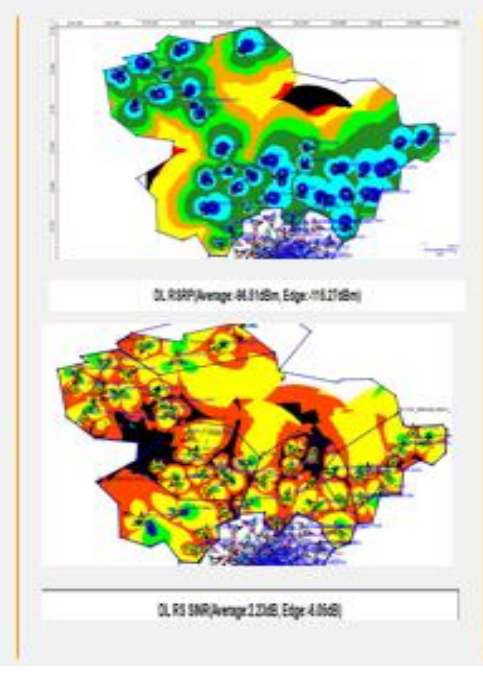

(b)

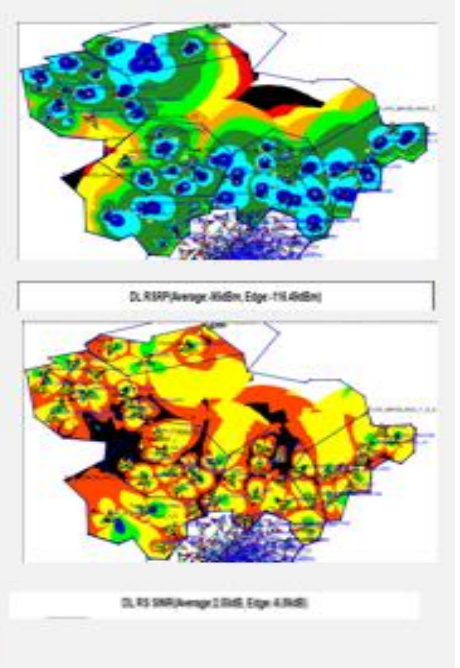

(c)

Gambar 11. Coverage Area Daerah Operasional Magelang(a) Drive Test Pertama (b) Drive Test Kedua (c) Coverage Prediction

Tabel 5. Hasil Coverage Prediction Parameter RSRP dan SINR Daerah Operasional Magelang

\begin{tabular}{|c|c|c|c|c|c|c|c|c|}
\hline \multirow{3}{*}{$\begin{array}{c}\text { Polygon } \\
1 \\
\end{array}$} & \multicolumn{4}{|c|}{$50 \%$ RSRP $(\mathrm{dBm})$} & \multicolumn{4}{|c|}{$50 \% \operatorname{SINR}(\mathrm{dB})$} \\
\hline & \multicolumn{2}{|c|}{ Before } & \multicolumn{2}{|c|}{ After } & \multicolumn{2}{|c|}{ Before } & \multicolumn{2}{|c|}{ After } \\
\hline & $-86,5$ & $-98,5$ & $-86,3$ & $-98,2$ & 2,7 & $-4,4$ & 3,7 & $-4,1$ \\
\hline 2 & $-86,7$ & $-101,3$ & $-86,4$ & $-100,8$ & 2,1 & $-6,1$ & 2,1 & $-6,4$ \\
\hline 3 & $-94,6$ & $-113,9$ & $-94,2$ & $-113,5$ & 0,9 & $-8,1$ & 1 & $-8,1$ \\
\hline 4 & $-97,4$ & $-107,3$ & $-94,1$ & $-111,6$ & 9,9 & $-3,4$ & 6,6 & $-3,6$ \\
\hline 5 & $-93,33$ & $-111,7$ & $-92,8$ & -112 & 2,7 & $-7,4$ & 3,1 & $-5,9$ \\
\hline 6 & $-101,7$ & $-115,97$ & $-96,8$ & -116 & 3,5 & -5 & 3,52 & $-4,9$ \\
\hline
\end{tabular}

Coverage Area untuk drive test pertama dan kedua ditampilkan pada Gambar 11(a) dan Gambar 11(b) sementara coverage prediction ditunjukkan oleh Gambar 11(c). Hasil drive test pertama dan drive test kedua menunjukkan bahwa kinerja RSRP dan SINR tidak terjadi perubahan sama sekali. Namun setelah dilakukan saran perbaikan, kinerja $50 \%$ sample pengukuran daerah operasional meningkat. $R S R P$ semula bernilai $-96.51 \mathrm{dBm}$ menjadi $-95 \mathrm{dBm}$, dan SINR yang semula bernilai 2,23 dB menjadi 2,55 dB. Selanjutnya pada Tabel 5 ditunjukkan polygon yang berisi beberapa site baru dan kinerja parameternya. Setiap polygon mengandung beberapa site baru sesuai kebutuhan badspot. Jumlah site yang hendak ditambahkan mengikuti kebutuhan badspot ialah 15 site. 


\subsection{Analisis Alokasi PCI untuk penambahan site}

Engineer Parameter digunakan untuk melakukan analisis alokasi $P C I$ yang dimiliki oleh PT. Indosaat Ooredoo. Skenario perencanan PCI oleh perusahaan dilakukan dengan masing-masing diberi 3 kode unik yang selisihnya 1 angka untuk setiap sel sektornya.

Alokasi seperti yang dilakukan oleh perusahaan sangat mempengaruhi SINR mengingat sinkronisasi isyarat ditentukan oleh pergeseran kode yang ditentukan oleh PCI. Konflik PCI pada alokasi perusahaan terjadi pada badspot Q2 pada Gambar 12 (a) dan interferensi yang diakibatkan oleh konflik $P C I$ ditunjukkan pada Gambar 12(b). Terjadi konflik PCI L_SETURAN dengan PCI 129 dan L_PUNTADEWAIB_XXX dengan PCI 147. Kode menyebabkan PSS collusion karena azimuth antar sel sektor saling berhadapan. Jika dilakukan penurunan cakupan maka interferensi akan tetap terjadi di sekitar badspot karena jarak kedua site cukup dekat, sehingga harus dilakukan pergantian $P C I$ agar interferensi dapat dihilangkan.

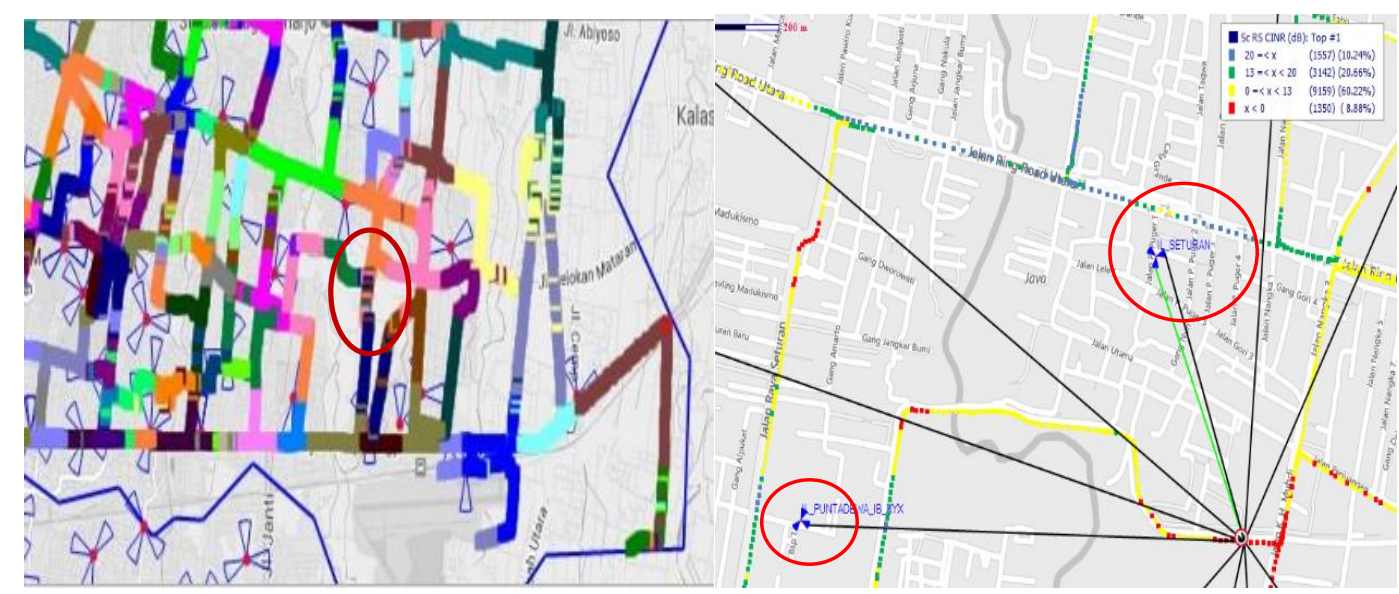

(a)

(b)

Gambar 12. Kolusi PCI pada Badspot Q2 (a) Parameter SINR dan (b) Pemetaan PCI

Alokasi PCI oleh perusahaan dibagi menjadi menjadi 168 grup PCI. Untuk meminimalkan pergeseran kode frekuensi maka dilakukan PCImod 3 untuk pemberian kode alokasi $P C I$. Sehingga jika dilakukan perhitungan alokasi $P C I$, akan didapatkan alokasi PCI yang ditunjukkan pada Tabel 6. Untuk identifikasi $P C I$ digunakan area pada Gambar 13 yang menunjukkan polygon pada daerah operasional Magelang. Polygon yang digunakan berjumlah 11 site yang terdiri dari 4 planning site yang ditandai dengan warna kuning dan 7 neighbour site yang bukan warna kuning.

Perhitungan ini merupakan skenario perancanaan PCI untuk site baru yang kemudian disimulasikan dengan perangkat perencanaan jaringan $U$-Net. Hasilnya dapat dilihat pada Tabel 7 yang mengindikasikan PCI collusion tidak terjadi untuk SSS. Pemberian kode SSS pada Tabel 7 sudah mengikuti kondisi PSS neighbour site. 


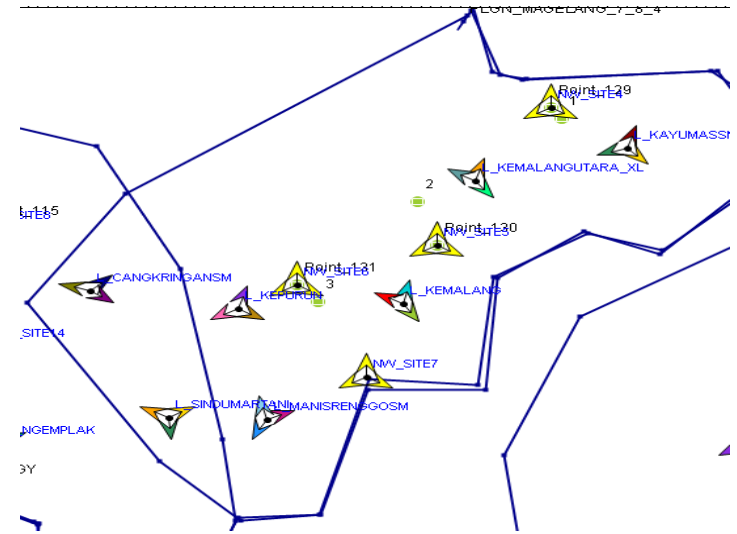

Gambar 13. Contoh Area yang Digunakan Untuk Analisis PCI.

Tabel 6. Skenario Perencanaan PCI untuk Penambahan Site.

\begin{tabular}{|c|c|c|c|c|c|c|c|c|c|}
\hline & 0 & 1 & 2 & 3 & $\ldots$. & 163 & 165 & 166 & 167 \\
\hline 0 & 0 & 3 & 6 & 18 & $\ldots$. & 489 & 492 & 498 & 501 \\
\hline 1 & 4 & 7 & 10 & 13 & $\ldots$. & 493 & 500 & 502 & 1 \\
\hline 2 & 8 & 11 & 14 & 17 & $\ldots .$. & 497 & 500 & 2 & 5 \\
\hline
\end{tabular}

Tabel 7. Kode SSS PCI polygon Gambar 13

\begin{tabular}{|c|c|c|c|c|c|c|c|c|c|c|}
\hline Cell Name & $\checkmark$ & Existing Code & $\checkmark$ & Suggest Code & 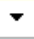 & Confirm Code & 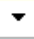 & Min Reuse Distance(m) & $\checkmark$ & Min Reuse Tiers \\
\hline NW_SITE6_1 & & 162 & & & & 162 & & No Reuse & & No Reuse \\
\hline NW_SITE6_2 & & 170 & & & & 170 & & 12123.83 & & Unreachable \\
\hline NW_SITE6_3 & & 166 & & & & 166 & & No Reuse & & No Reuse \\
\hline NW_SITE4_1 & & 147 & & & & 147 & & 22493.24 & & Unreachable \\
\hline NW_SITE4_2 & & 151 & & & & 151 & & No Reuse & & No Reuse \\
\hline NW_SITE4_3 & & 155 & & & & 155 & & No Reuse & & No Reuse \\
\hline NW_SITE5_1 & & 98 & & & & 98 & & 17751.07 & & Unreachable \\
\hline NW_SITE5_2 & & 94 & & & & 94 & & No Reuse & & No Reuse \\
\hline NW_SITE5_3 & & 90 & & & & 90 & & 15011.44 & & Unreachable \\
\hline NW_SITE7_1 & & 45 & & & & 45 & & No Reuse & & No Reuse \\
\hline NW_SITE7_2 & & 53 & & & & 53 & & No Reuse & & No Reuse \\
\hline NW_SITE7_3 & & 49 & & & & 49 & & 15673.13 & & Unreachable \\
\hline
\end{tabular}

\section{Kesimpulan}

1. Coverage Planning di Existing Network dengan penambahan 4 site yang dilakukan oleh perusahaan, menurut hasil drive test membuat peningkatan kinerja coverage RSRP pada daerah operasional Yogyakarta sebesar 16,13\% tetapi menurunkan kualitas SINR sebesar 26,28\% .

2. Coverage Planning di Existing Network dengan penambahan 1 site yang dilakukan oleh perusahaan pada daerah operasional Magelang, menurut hasil drive test tidak memberikan pengaruh karena terjadi penurunan kinerja parameter RSRP sebesar $8,67 \%$ dan penurunan kinerja SINR sebesar 2,82\%.

3. Hasil simulasi coverage area pada daerah operasional Yogyakarta menunjukkan peningkatan setelah dilakukan coverage prediction perencanaan 4 site. Total $50 \%$ dari keseluruhan data hasil pengukuran parameter RSRP yang semula bernilai 99,17 dBm, setelah dilakukan coverage prediction menjadi -98,79 dBm. Sementara untuk parameter SINR dengan total cakupan yang sama juga meningkat semula bernilai 1,03 dB menjadi 1,18 dB. 
4. Hasil simulasi coverage area pada daerah operasional Magelang menunjukkan peningkatan setelah dilakukan coverage prediction perencanaan 15 site. Total 50\% dari keseluruhan data hasil pengukuran parameter RSRP yang semula bernilai 96,51dBm, setelah dilakukan coverage prediction menjadi $-95 \mathrm{dBm}$. Sementara untuk parameter SINR dengan total cakupan yang sama juga meningkat semula bernilai 2,23 dB menjadi 2,55 dB.

5. Dengan menggunakan skenario Planning PCI alternatif untuk penambahan site, dapat diketahui $P C I$ antar site yang berbeda tidak terjadi kolusi $P C I$.

\section{Daftar Pustaka}

[1] Debora Lidya Tamtomo, Eva Yovita Dwi Utami, "Analisis Kinerja Coverage dan Kualitas Sinyal 4G LTE pada Operator Seluler di Kota Purbalingga", Jurnal Media Elektrika, Vol. 10, No. 2, Desember 2017

[2] Putra, Ikha Dalinar Kurnia," Analisis Perencanaan Jaringan Long Term Evolution (LTE) dengan Physical Cell Identity", Skripsi Fakultas Teknik Elektro Progdi Teknik Telekomunikasi - Universitas Telkom 2014.

[3] Huawei Confidential, Genex U-Net Wireless Network Planning Software User Manual [Online], http: / / www . huawei.com, diakses tanggal 22 Agustus 2017.

[4] Elnashar, Almar, Design, deployment and performance of 4G-LTE networks : A Practical Approach, United Kingdom: Wiley.2014

[5] Huawei Confidential, Optimization Guide LTE RNP [Online] https://www.slideshare.net/tharinduwije/lte-optimization, diakses tanggal 30 Agustus 2017. 